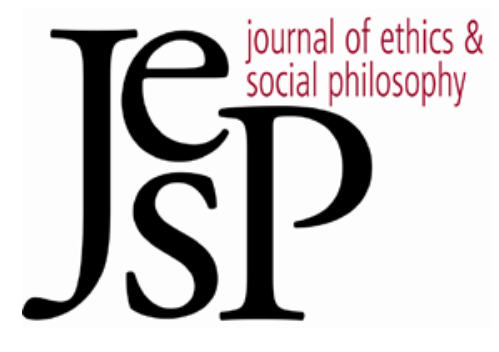

DISCUSSION NOTE

\title{
Are the Moral Fixed Points Conceptual Truths?
}

BY DAAN EVERS AND BART StREUMER

JOURNAL OF ETHICS \&SOCIAL PHILOSOPHY

DISCUSSION NOTE | MARCH 2016 URL: WWW.JESP.ORG COPYRIGHT (C) DAAN EVERS AND BART STREUMER 2016 


\title{
Are the Moral Fixed Points Conceptual Truths?
}

\author{
Daan Evers and Bart Streumer
}

\begin{abstract}
DERENCE CUNEO AND RUSS SHAFER-LANDAU have recently proposed a new version of moral nonnaturalism, according to which there are nonnatural moral concepts and truths but no nonnatural moral facts. ${ }^{1}$ This view entails that moral error theorists are conceptually deficient. We explain why moral error theorists are not conceptually deficient. We then argue that this explanation reveals what is wrong with Cuneo and Shafer-Landau's view.
\end{abstract}

\section{Cuneo and Shafer-Landau's New Version of Moral Nonnatural- ism}

Consider the following propositions:

(1) It is wrong to engage in the recreational slaughter of a fellow person. ${ }^{2}$

(2) It is morally admirable to express gratitude to a benefactor whose gift resulted from substantial sacrifice undertaken from exclusively altruistic motives.

(3) There is some moral reason to offer aid to those in distress, if such aid is very easily given and comes at very little expense.

According to Cuneo and Shafer-Landau, propositions like (1), (2) and (3) have "framework status, fixing the boundaries as to what counts as a type of subject matter": a normative system that fails to incorporate these propositions is not a moral system, but is instead a normative system of some other kind. ${ }^{3}$ They therefore take propositions like (1), (2) and (3) to be conceptual truths, which they call "the moral fixed points." 4

Cuneo and Shafer-Landau think that conceptual truths are made true by the essences of their constituent concepts. If so, the proposition that

(4) Unmarried men are bachelors

is made true by the essences of the concepts UNMARRIED MAN and BACHELOR: the essences of these concepts are such that anything that satisfies the concept UNMARRIED MAN thereby satisfies the concept

\footnotetext{
${ }^{1}$ Cuneo and Shafer-Landau (2014). Cuneo and Shafer-Landau argue that nonnaturalists can also say that there are nonnatural moral facts, but they take this to be an optional addition to their version of nonnaturalism. We will ignore this optional addition, since it does not affect our arguments.

2 Like Cuneo and Shafer-Landau, we use the term "wrong" to mean pro tanto wrong.

${ }^{3}$ Cuneo and Shafer-Landau (2014: 407).

${ }_{4}$ They also give three other reasons for taking the moral fixed points to be conceptual truths: that if these propositions are true, they are necessarily true; that if they are knowable, they are knowable a priori; and that denying them tends to evoke "bewilderment" (2014: 407-8). We return to this in n. 9.
} 
BACHELOR. Similarly, Cuneo and Shafer-Landau think, the proposition that

(1) It is wrong to engage in the recreational slaughter of a fellow person

is made true by the essences of the concepts RECREATIONAL SLAUGHTER OF A FELLOW PERSON and WRONG: the essences of these concepts are such that anything that satisfies the concept RECREATIONAL SLAUGHTER OF A FELLOW PERSON thereby satisfies the concept WRONG.

Cuneo and Shafer-Landau take moral concepts like WRONG to be nonnatural concepts, in the sense that these concepts are not equivalent to any natural concept. They therefore think that nonnaturalists need not say that propositions like (1), (2) and (3) are made true by nonnatural facts, but can instead say that such propositions are made true, in part, by nonnatural concepts.

(1), (2) and (3) are general moral propositions. What about particular moral propositions? Suppose that Fred is engaging in the recreational slaughter of a fellow person. In that case, Cuneo and Shafer-Landau think, the true proposition that

(1) It is wrong to engage in the recreational slaughter of a fellow person

and the true proposition that

(5) Fred is engaging in the recreational slaughter of a fellow person

together make it true that

(6) Fred's action is wrong.

Since (1) and (5) together make (6) true, Cuneo and Shafer-Landau think that (6) is made true by the essences of (1)'s constituent concepts, one of which is a nonnatural concept, together with the natural fact that makes (5) true. They therefore think that nonnaturalists need not say that particular moral propositions like (6) are made true by nonnatural facts either.

Almost all philosophers agree that moral concepts like WRONG are nonnatural concepts, in the sense that these concepts are not equivalent to any natural concept. ${ }^{5}$ Standard nonnaturalism is controversial not because it says that there are nonnatural moral concepts in this sense, but because it says that there are nonnatural moral facts. Since Cuneo and Shafer-Landau's version of nonnaturalism avoids this controversial commitment, it may seem more attractive than standard nonnaturalism.

5 Though, as Cuneo and Shafer-Landau note, Jackson (1998) denies this. So does Finlay (2014). 


\section{Why the Moral Fixed Points Are Not Conceptual Truths}

Cuneo and Shafer-Landau's view avoids a commitment to nonnatural facts by taking on a different controversial commitment instead - namely, by saying that (1), (2), (3) and the other moral fixed points are conceptual truths. According to Cuneo and Shafer-Landau, anyone who denies these propositions is "conceptually deficient": such a person either lacks moral concepts or fails to see that the essences of these concepts make propositions like (1), (2) and (3) true. ${ }^{6}$ Since moral error theorists deny that anything is wrong, morally admirable or a moral reason, they deny that (1), (2) and (3) are true. ${ }^{7}$ Cuneo and Shafer-Landau's view therefore entails that moral error theorists are conceptually deficient. ${ }^{8}$

Are Cuneo and Shafer-Landau right that (1), (2), (3) and the other moral fixed points are conceptual truths? Consider a different concept: the concept GOD. Suppose that a Christian thinks that

(7) Benevolence is rewarded by God.

This Christian may think that (7) has what Cuneo and Shafer-Landau call "framework status": he or she may think that a faith that fails to incorporate (7) is not a form of Christianity, but is instead a faith of some other kind. Just as Cuneo and Shafer-Landau take (1), (2) and (3)'s framework status to show that (1), (2) and (3) are conceptual truths, this Christian may take (7)'s framework status to show that (7) is a conceptual truth. And if this Christian endorses Cuneo and Shafer-Landau's view that conceptual truths are made true by the essences of their constituent concepts, he or she will think that (7) is made true by the essences of the concepts BENEVOLENCE and REWARDED BY GOD: he or she will think that the essence of these concepts is such that anything that satisfies the concept BENEVOLENCE thereby satisfies the concept REWARDED BY GOD.

But, of course, (7) is not a conceptual truth. For it is not a conceptual truth that God exists, and if God does not exist, something that satisfies the concept BENEVOLENCE does not thereby satisfy the concept REWARDED BY GOD. The essences of these concepts therefore do not

\footnotetext{
${ }^{6}$ This person may fail to see this either because he or she has what Cuneo and ShaferLandau call an "inadequate" or "confused" grasp of these concepts, of because he or she "fails to appreciate or acknowledge the manifest implications" of these concepts (2014: 413).

${ }^{7}$ For defenses of a moral error theory, see Mackie (1977), Joyce (2001), Streumer (2013) and Olson (2014).

8 As Ingram (2015) argues, this implication by itself throws doubt on Cuneo and ShaferLandau's view. One of us has defended an error theory about all normative judgements and has argued that we cannot believe this error theory, which means that he himself does not believe this theory either (Streumer 2013). But since this error theory implies that (1), (2) and (3) are false, Cuneo and Shafer-Landau will presumably say that this theory is conceptually false, and that its defender is therefore conceptually deficient.
} 
make (7) conceptually true, but at most make it conceptually true that

(7*) If anything is rewarded by God, benevolence is rewarded by God.

Similar claims apply to (1), (2) and (3). It is not a conceptual truth that wrongness is instantiated, and if wrongness is not instantiated, something that satisfies the concept RECREATIONAL SLAUGHTER OF A FELLOW PERSON does not thereby satisfy the concept WRONG. The essences of these concepts therefore do not make (1) conceptually true, but at most make it conceptually true that

$\left(1^{*}\right)$ If anything is wrong, it is wrong to engage in the recreational slaughter of a fellow person.

Similarly, the essences of (2) and (3)'s constituent concepts do not make (2) and (3) conceptually true, but at most make it conceptually true that

(2*) If anything is morally admirable, it is morally admirable to express gratitude to a benefactor whose gift resulted from substantial sacrifice undertaken from exclusively altruistic motives,

and that

$\left(^{*}\right)$ If anything is a moral reason, there is some moral reason to offer aid to those in distress that is very easily given and comes at very little expense.

Cuneo and Shafer-Landau may be right that (1), (2) and (3) have "framework status": they may be right that a normative system that fails to incorporate (1), (2) and (3) is not a moral system. But this only shows that it is conceptually true that if anything satisfies the constituent moral concepts of (1), (2) and (3), then (1) (2) and (3) are true. In other words, it only shows that $\left(1^{*}\right),\left(2^{*}\right)$ and $\left(3^{*}\right)$ are conceptually true. Since $\left(1^{*}\right),\left(2^{*}\right)$ and $\left(3^{*}\right)$ do not say or entail that anything is in fact wrong, morally admirable or a moral reason, moral error theorists can accept $\left(1^{*}\right),\left(2^{*}\right)$ and $\left(3^{*}\right) .{ }^{9}$ If $\left(1^{*}\right),\left(2^{*}\right)$ and $\left(3^{*}\right)$ are conceptual truths, it therefore does not follow that moral error theorists are conceptually deficient. ${ }^{10}$

\footnotetext{
9 Moreover, moral error theorists can also agree with Cuneo and Shafer-Landau that if (1), (2) and (3) are true, they are necessarily true (while denying that (1), (2) and (3) are in fact true); they can agree that if (1), (2) and (3) are knowable, they are knowable a priori (while denying that (1), (2) and (3) are in fact knowable); and they can agree that denying (1), (2) and (3) tends to evoke bewilderment (while saying that such denials tend to evoke bewilderment not because (1), (2) and (3) are conceptual truths, but because a moral error theory is, as Olson (2014: 143), puts it, "emotionally difficult to accept").

${ }_{10}$ Cuneo and Shafer-Landau also say that when moral error theorists reject "highly evident first-order moral propositions such as that it is wrong to engage in recreational slaughter of a fellow person" by appealing to "highly controversial metaethical claims such as [the claim that] there are no categorical reasons," they are employing a "prob-
} 
Cuneo and Shafer-Landau could reply that if (1) has to be revised to $\left(1^{*}\right)$ to turn it into a conceptual truth, it is hard to see why the proposition that

(4) Unmarried men are bachelors

does not similarly have to be revised to

(4*) If anything is a bachelor, unmarried men are bachelors

to turn it into a conceptual truth. But (4) clearly does not have to be revised to $\left(4^{*}\right)$ to turn it into a conceptual truth. So why, Cuneo and ShaferLandau could ask, should we think that $(1)$ has to be revised to $\left(1^{*}\right)$ to turn it into a conceptual truth?

The answer is that since the concept BACHELOR is identical to the concept UNMARRIED MAN, the satisfaction of the concept BACHELOR does not require more of the world than the satisfaction of the concept UNMARRIED MAN does. That is why (4) does not have to be revised to $\left(4^{*}\right)$ to turn it into a conceptual truth. By contrast, the satisfaction of the concept REWARDED BY GOD requires something of the world that the satisfaction of the concept BENEVOLENCE does not - namely, the existence of God. That is why $(7)$ has to be revised to $\left(7^{*}\right)$ to turn it into a conceptual truth. Similarly, the satisfaction of the concept WRONG also requires something of the world that the satisfaction of the concept RECREATIONAL SLAUGHTER OF A FELLOW PERSON does not - namely, the instantiation of wrongness. That is why (1) also has to be revised to $\left(1^{*}\right)$ to turn it into a conceptual truth.

Cuneo and Shafer-Landau could reply that, whereas the world has to be a certain way for God to exist, the world does not have to be a certain way for wrongness to be instantiated, at least not over and above containing recreational slaughter or instantiations of other natural properties that make actions satisfy the concept WRONG. If they reject our parallel between (7) and (1) in this way, they can agree that (7) has to be revised to $(7 *)$ to turn it into a conceptual truth, but deny that (1) similarly has to be revised to $\left(1^{*}\right)$ to turn it into a conceptual truth.

But if Cuneo and Shafer-Landau say this, that will make their view much less attractive to their fellow nonnaturalists. For consider an antimoralist who lacks the concept WRONG and instead has the concept $W_{R O N G}$ anti. Imagine that this concept plays the same role in this antimoralist's thought and action as the concept WRONG does in ours: the

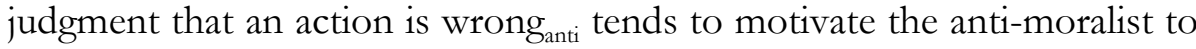
avoid this action, the anti-moralist tends to blame people for disregarding wrongness $_{\text {anti }}$ and so on. This anti-moralist may take it to be a conceptual

lematic" methodology (2014: 438). For a response to this charge, see Ingram (2015). 
truth that

(9) It is wrong anti to stop people from engaging in the recreational slaughter of a fellow person.

Of course, we want to say that the concept that should guide people's behavior is WRONG rather than WRONG ${ }_{\text {anti: }}$ But the anti-moralist can simi-

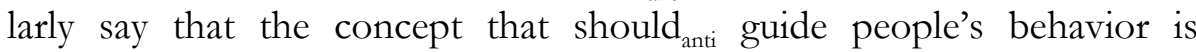
$W_{R O N G}$ anti rather than WRONG. We may want to accuse the anti-moralist of being irrational. But the anti-moralist can similarly accuse us of being irrational $_{\text {anti }}-$ and so on for any other normative concept. ${ }^{11}$

Standard nonnaturalists think that something breaks this deadlock: they think that concepts like WRONG, SHOULD and IRRATIONAL ascribe properties that are really instantiated, whereas concepts like $\mathrm{WRONG}_{\text {anti, }}$, SHOULD $_{\text {anti }}$ and IRRATIONAL ${ }_{\text {anti }}$ ascribe properties that are not really instantiated. ${ }^{12}$ They can admit that it is a conceptual truth that

(9*) If anything is wrong antis it is wronganti to stop people from engaging in the recreational slaughter of a fellow person.

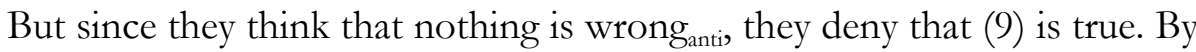
contrast, if Cuneo and Shafer-Landau say that the world does not have to be a certain way for wrongness to be instantiated over and above containing instantiations of natural properties that make actions satisfy the concept WRONG, it is hard to see how they can avoid admitting that (9) is a conceptual truth. For if all that is required for the instantiation of wrongness is the existence of the concept WRONG and the instantiation of natural properties that make actions satisfy this concept, all that is required

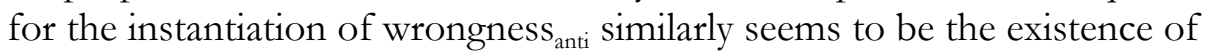
the concept $W_{R O N G}$ anti and the instantiation of natural properties that make actions satisfy that concept. If Cuneo and Shafer-Landau say this, therefore, their view no longer seems to be a form of realism. That will undermine its attractiveness to their fellow nonnaturalists. ${ }^{13}$

\footnotetext{
11 And also for truth if we accept a deflationary account of the truth of normative propositions.

12 Of course, that standard nonnaturalists think this does not mean that it is true. Error theorists think it is false: they think that concepts like WRONG, SHOULD and IRRATIONAL also ascribe properties that are not instantiated.

13 This point is similar to the objections from "shmeasons" and "counter-reasons" that McPherson (2011) and Enoch (2011) make to quietism. That is no coincidence: if Cuneo and Shafer-Landau deny that the world has to be a certain way for wrongness to exist, their view comes close to being a version of quietism.
} 


\section{Why It Matters Whether the Moral Fixed Points Are Conceptual Truths}

Cuneo and Shafer-Landau may now agree that (1), (2) and (3) are not conceptual truths and that moral error theorists are therefore not conceptually deficient. But they may say that this does not matter, since they did not aim to refute the moral error theory but merely to convert other realists to their new version of nonnaturalism.

But if (1), (2) and (3) are not conceptual truths, this does undermine Cuneo and Shafer-Landau's view. For if it is not a conceptual truth that

(1) It is wrong to engage in the recreational slaughter of a fellow person

then nonnaturalists cannot say that (1) is made true by the essences of the concepts RECREATIONAL SLAUGHTER OF A FELLOW PERSON and WRONG: they cannot say that the essences of these concepts are such that anything that satisfies the concept RECREATIONAL SLAUGHTER OF A FELLOW PERSON thereby satisfies the concept WRONG. Instead, unless more is said, they will have to say that claims like (1), (2) and (3) are made true by nonnatural moral facts. In other words, they will have to revert to standard nonnaturalism about general moral propositions.

And suppose again that Fred is engaging in the recreational slaughter of a fellow person. The true proposition that

$\left(1^{*}\right)$ If anything is wrong, it is wrong to engage in the recreational slaughter of a fellow person

and the true proposition that

(5) Fred's action is the recreational slaughter of a fellow person

do not together make it true that

(6) Fred's action is wrong.

This means that if (1) is not a conceptual truth, nonnaturalists cannot say that a particular moral proposition like (6) is made true by the essences of (1)'s constituent concepts together with the natural fact that makes (5) true. Instead, unless more is said, they will have to say that (6) is, at least in part, made true by a nonnatural fact: either by a particular nonnatural fact or by a natural fact together with the more general nonnatural fact that makes (1) true. In other words, they will have to revert to standard nonnaturalism about particular moral propositions as well.

We therefore conclude that Cuneo and Shafer-Landau's defense of their new version of nonnaturalism fails. Since the moral fixed points are 
not conceptual truths, moral nonnaturalists cannot avoid being committed to the existence of nonnatural facts in the way Cuneo and ShaferLandau propose. ${ }^{14}$

Daan Evers

University of Groningen

Faculty of Philosophy

h.w.a.evers@rug.nl

Bart Streumer

University of Groningen

Faculty of Philosophy

b.streumer@rug.nl

14 We are grateful to Terence Cuneo, Niels van Miltenburg and several anonymous referees for helpful comments. 


\section{References}

Cuneo, T. and Shafer-Landau, R. (2014) "The Moral Fixed Points: New Directions for Moral Nonnaturalism," Philosophical Studies 171: 399-443.

Enoch, D. (2011) Taking Morality Seriously, Oxford: Oxford University Press.

Finlay, S. (2014) Confusion of Tongues, Oxford: Oxford University Press.

Ingram, S. (2015) "The Moral Fixed Points: Reply to Cuneo and Shafer-Landau," Journal of Ethics and Social Philosophy.

Jackson, F. (1998) From Metaphysics to Ethics, Oxford: Oxford University Press.

Joyce, R. (2001) The Myth of Morality, Cambridge: Cambridge University Press.

Mackie, J. L. (1977) Ethics: Inventing Right and Wrong, Harmondsworth: Penguin.

McPherson, T. (2011) “Against Quietist Normative Realism," Philosophical Studies 154: 223-40.

Olson, J. (2014) Moral Error Theory, Oxford: Oxford University Press.

Streumer, B. (2013) “Can We Believe the Error Theory?” Journal of Philosophy 110: 194212. 